\title{
Pengaruh Kecerdasan Emosional terhadap Prestasi Belajar Matematika Siswa SMP Negeri 1 Kapontori
}

\author{
Azis \\ Universitas Dayanu Ikhsanuddin \\ azis.nasam@gmail.com
}

\begin{abstract}
ABSTRAK
Tujuan penelitian ini adalah untuk mengetahui pengaruh kecerdasan emosional terhadap prestasi belajar matematika siswa pada kelas VIII SMP Negeri 1 Kapontori. Penelitian ini merupakan penelitian ex-post facto. Penelitian dilakukan di SMP Negeri 1 Kapontori. Populasi dalam penelitian ini adalah seluruh siswa kelas VIII di SMP Negeri 1 Kapontori yang berjumlah 53 siswa. Instrumen yang digunakan dalam penelitian ini berupa kuesioner dan tes prestasi belajar siswa. Validitas kuesioner menggunakan validitas isi dan validitas konstruk. Reliabilitas dihitung dengan rumus Cronbach Alpha. Pengujian hipotesis menggunakan analisis regresi linear sederhana. Hasil penelitian ini adalah: 1) rata-rata data kecerdasan emosional sebesar 77,91 dengan simpangan baku sebesar 9,375 dan 2) rata-rata data tes prestasi belajar matematika sebesar 68.87 berdasarkan hasil analisis inferensial dengan melihat uji normalitas terdapat nilai signifikan kecerdasan emosional dan prestasi belajar sebesar 0,200. nilai konstan sebesar 27,472. Koefisien regresi untuk variabel kecerdasan emosional sebesar 0,524. Sehingga diperoleh persamaan regresi sederhana $y=$ $27,427+0,524 x$. R Square yang diperoleh sebesar 0,508 yang menandakan bahwa faktor kecerdasan emosi memberikan pengaruh terhadap prestasi belajar matematika sebesar $50,8 \%$, sedangkan 49,2\% selebihnya dipengaruhi oleh faktor-faktor lain yang tidak diteliti dalam penelitian ini. Sehingga dapat disimpulkan bahwa ada pengaruh kecerdasan emosional terhadap prestasi belajar siswa kelas VIII SMP Negeri 1 Kapontori.
\end{abstract}

Kata kunci: kecerdasan emosional, prestasi belajar matematika.

\section{ABSTRACT}

The purpose of this study was to see emotional quotient on mathematics learning achievement of students in class VIII SMP Negeri 1 Kapontori. This research is an ex-post facto research. The research was conducted at SMP Negeri 1 Kapontori. The population in this study were all students of class VIII at SMP Negeri 1 Kapontori, which may be 53 students. The instruments used in this study were questionnaires and student achievement tests. The validity of the questionnaire used content validity and construct validity. Reliability is calculated using the Cronbach Alpha formula. Hypothesis testing uses simple linear regression analysis. The results of this study are: 1) the average data intelligence intelligence is 77.91 with a standard deviation of 9.375 and 2) the average data on the mathematics learning achievement test is 68.87 based on the results of inferential analysis by looking at the normality test, there is a significant value of emotional quotient and learning achievement of 0.200. a constant value of 27.472. The regression coefficient for the emotional quotient variable is 0.524 . So the equation is a simple regression equation $y=27,427+$ $0,524 x$. The $R$ Square obtained is 0.508 which indicates that the intelligence factor has an effect on mathematics learning achievement by 50.8\%, while the rest $49.2 \%$ is from other factors not examined in this study. So that can be that show that is attention to the learning achievement of class VIII students of SMP Negeri 1 Kapontori.

Keywords: emotional quotient, mathematics learning achievement. 


\section{PENDAHULUAN}

Pendidikan merupakan suatu kegiatan atau usaha yang dijalankan dengan sengaja, teratur dan terencana dengan maksud mengubah atau mengembangkan perilaku yang diinginkan. Sekolah sebagai lembaga formal merupakan sarana dalam rangka pencapaian tujuan pendidikan tersebut. Melalui sekolah, siswa belajar berbagai macam hal. Dalam pendidikan formal belajar menunjukkan adanya perubahan yang sifatnya positif sehingga pada tahap akhir akan di perolah keterampilan, kecakapan dan pengetahuan baru.

Menurut pendapat Bruner (Rosida, 2015) menyatakan bahwa "belajar matematika adalah belajar tentang konsep-konsep dan struktur-struktur matematika yang terdapat dalam materi yang dipelajari serta mencari hubungan-hubungan antara konsep-konsep dan struktur-struktur matematika itu". Proses belajar yang terjadi pada individu memang merupakan sesuatu yang penting, karena melalui belajar individu mengenal lingkungannya dan menyesuaikan diri dengan lingkungan disekitarnya. Menurut Irwanto (Firmansyah, 2010) belajar merupakan proses perubahan dari belum mampu menjadi mampu dan terjadi dalam waktu tertentu. Dengan belajar, siswa dapat mewujudkan cita-cita yang diharapkan.

Proses belajar di sekolah adalah proses yang sifatnya kompleks dan menyeluruh. Banyak orang yang berpendapat bahwa untuk meraih prestasi yang tinggi dalam belajar, seseorang harus memiliki Intelligence Quotient (IQ) yang tinggi, karena inteligensi merupakan bekal potensial yang memudahkan dalam belajar dan pada gilirannya akan menghasilkan prestasi belajar yang optimal. Menurut Binet dalam Winkel (Gusniwati, 2015) hakikat intelegensi adalah kemampuan untuk menetapkan dan mempertahankan suatu tujuan, untuk mengadakan penyesuaian dalam rangka mencapai tujuan itu, dan untuk menilai keadaan diri secara kritis dan objektif.

Kenyataannya, dalam proses belajar mengajar di sekolah sering ditemukan siswa yang tidak dapat meraih prestasi belajar yang setara dengan kemampuan intelegensinya. Ada siswa yang mempunyai kemampuan intelegensi tinggi tetapi memperoleh prestasi belajar yang relatif rendah, namun ada siswa yang walaupun kemampuan intelegensinya relatif rendah dapat meraih prestasi belajar yang relatif tinggi. Itu sebabnya taraf intelegensi bukan merupakan satusatunya faktor yang menentukan keberhasilan seseorang, karena ada faktor lain yang mempengaruhi. Menurut Goleman (Gusniwati, 2015), kecerdasan intelektual (IQ) hanya menyumbang $20 \%$ bagi kesusksesan, sedangkan $80 \%$ adalah sumbangan faktor kekuatankekuatan lain, diantaranya adalah kecerdasan emosional atau Emotionanl Quotient (EQ) yakni kemampuan memotivasi diri sendiri, mengatasi frustasi, mengontrol desakan hati, mengatur suasana hati (mood), berempati serta kemampuan bekerja sama.

Dalam proses belajar siswa, kedua intelegensi itu sangat di perlukan. IQ tidak dapat berfungsi dengan baik tanpa partisipasi penghayatan emosional terhadap mata pelajaran yang disamapaikan di sekolah. Namun biasanya kedua intelegensi itu saling melengkapi. Keseimbangan antara IQ dan EQ merupakan kunci keberhasilan belajar siswa di sekolah. Goleman (Gusniwati, 2015). Pendidikan di sekolah bukan hanya perlu mengembangkan rational intelligence yaitu model pemahaman yang lazimnya dipahami siswa saja, melainkan juga perlu mengembangkan emotional intelligence siswa.

Harus diakui bahwa mereka yang memiliki IQ rendah dan mengalami keterbelakangan mental akan mengalami kesulitan, bahkan mungkin tidak mampu mengikuti pendidikan formal 
yang seharusnya sesuai dengan usia mereka. Namun fenomena yang ada menunjukkan bahwa tidak sedikit orang yang memiliki IQ tinggi berprestasi rendah dan ada banyak orang dengan IQ sedang yang dapat mengungguli prestasi belajar orang dengan IQ tinggi, hal ini menunjukkan bahwa IQ tidak selalu memperkirakan prestasi belajar seseorang.

Kemunculan istilah kecerdasan emosional dalam pendidikan, bagi sebagian orang mungkin dianggap sebagai jawaban atau kejanggalan tersebut. Teori Daniel Goleman, sesuai dengan judul bukunya, memberikan definisi baru terhadap kata cerdas. Walaupun EQ merupakan hal yang relatif baru dibandingkan IQ, namun beberapa penelitian telah mengisyaratkan bahwa kecerdasan emosional tidak kalah penting dengan IQ. Menurut (Goleman, 2015) setinggi-tingginya, IQ menyumbang kira-kira 20\% bagi faktor-faktor yang menentukan sukses dalam hidup, maka yang $80 \%$ diisi oleh kekuatan-kekuatan lain. Salah satu kekuatan lain itu adalah kecerdasan emosional atau Emotional Quotient (EQ)..

Menurut Goleman (Gusniwati, 2015), kecerdasan emosional adalah kemampuan seseorang mengatur emosinya dengan inteligensi (to manage our emotional life with intelligence); menjaga keselarasan emosi dan pengungkapannya (the approprianteness of emotional and is exspression) melaui keterampilan kesadaran diri, pengendalian diri, motivasi diri, empati dan keterampilan sosial.

Realita saat ini yang membuat hidup seorang siswa kurang terkontrol adalah karena kurang mempunyai impian besar, dalam artian kurang ada keinginan berprestasi dalam belajar kedepannya seperti apa. Sebagian besar mereka menganggap semuanya gampang tanpa harus lebih berusaha. Tetapi, tidak sedikit juga dari siswa yang kurang memiliki IQ tinggi justru memiliki prestasi belajar yang lumayan bagus. Dari hal-hal tersebut dapat disimpulkan adanya indikasi kecerdasan emosional yang rendah. Disisi lain, ada sebagian siswa yang memiliki kecerdasan emosional yang cukup tinggi, selalu menjadikan tuntutan tugas yang diberikan oleh guru-gurunya biasa meraih prestasi belajar yang bagus.

Individu yang memiliki tingkat kecerdasan emosional yuang lebih baik, dapat menjadi lebih terampil dalam menenangkan dirinya dengan cepat, jarang tertular penyakit, lebih terampil dalam memusatkan perhatian, lebih baik dalam berhubungan dengan orang lain, lebih cakap dalam memahami orang lain dan untuk kerja akademis disekolah lebih baik (Gottman et al., 1998).

Kecerdasan emosional mencakup kemampuan yang berbeda, tetapi mempengaruhi kecerdasan akademik (academic intelligence). Orang tidak akan mampu menggunakan kemampuan kognitif mereka sesuai dengan potensi yang maksimum tanpa memiliki kecerdasan emosional. Kecerdasan emosional memiliki peran yang sangat penting untuk mencapai kesuskesan di sekolah maupun dalam berkomunikasi di lingkungan masyarakat. Kecerdasan emosional mencakup kemampuan yang berbeda-beda, tetapi saling melengkapi dengan kecerdasan akademik (academic intelligence).

Keterampilan dasar emosional tidak dapat dimiliki secara tiba-tiba tetapi membutuhkan proses dalam mempelajarinya dan lingkungan yang membentuk kecerdasan emosional tersebut besar pengaruhnya. Hal positif akan diperoleh bila anak diajarkan keterampilan dasar kecerdasan emosional, secara emosional akan lebih cerdas, penuh pengertian, mudah menerima perasaan-perasaan dan lebih banyak pengalaman dalam memecahkan permasalahannya sendiri, sehingga pada saat remaja akan lebih banyak suskses di sekolah dan dalam berhubungan dengan 
rekan-rekan sebaya serta akan terlindung dari resiko-resiko seperti obat-obat terlarang, kenakalan, kekerasan serta seks yang tidak aman (Gottman et al., 1998).

Dari uraian diatas dapat di ambil kesimpulan bahwa kecerdasan emosional merupakan salah satu faktor penting yang seharusnya dimiliki oleh siswa yang memiliki kebutuhan untuk meraih prestasi belajar yang lebih baik di sekolah, karena kecerdasan emosional sangat berpengaruh terhadap prestasi belajar siswa.

Realita saat ini cukup menarik untuk diteliti, karena bila merujuk pada teori seharusnya bila seseorang memiliki kecenderungan emosional yang tinggi maka individu tersebut berpeluang untuk mendapatkan prestasi belajar yang tinggi. Sebaliknya, bila seseorang memiliki kecerrdasan emosional yang relatif rendah, maka seseorang tersebut tentu berpeluang untuk mendapatkan prestasi belajar yang relatif rendah. Sedangkan pada realita diatas disebutkan bahwa yang terjadi justru sebaliknya, yakni individu yang kurang memiliki kecerdasan emosional tinggi bisa meraih prestasi belajar yang bisa dibanggakan.

Siswa kelas VIII SMP Negeri 1 Kapontori termasuk dalam tahap perkembangan anak usia sekolah. Harapan mereka untuk mengetahui sesuatu akan bertambah kuat dan terkait erat dengan perjuangan dasar untuk mencapai kompetensi. Dalam perkembangan yang normal anak-anak berjuang secara produktif untuk bisa belajar kemampuan-kemampuan yang diperlukan.

Tahap ini meliputi produktivitas versus inferioritas (kemampuan menghasilkan versus rasa tidak berguna). Pada masa sekolah (School Age) ditandai adanya kecenderungan industryinferiority. Sebagai kelanjutan dari perkembangan tahap sebelumnya, pada masa ini anak sangat aktif mempelajari apa saja yang ada di lingkungannya. Dorongan untuk mengetahui dan berbuat terhadap lingkungannya yang sangat besar, tetapi dipihak lain karena keterbatasan dalam kemampuan dan pengetahuannya kadang-kadang dia menghadapi kesukaran, hambatan bahkan kegagalan. Hambatan dan kegagalan ini dapat menyebabkan anak merasa dirinya tidak berguna, tidak bisa berbuat apa-apa. Tahap ini di katakan juga sebagai tahap laten yang terjadi pada usia sekolah antara umur 6 sampai 13 tahun.

Dari paparan mengenai perkembangan emosional anak usia sekolah, dapat diketahui pada tahapan ini anak harus belajar bekerja keras mengembangkan sikap rajin. Dapat pula anak merasa tidak mampu (inferioritas) sehingga anak merasa dirinya tidak dapat melakukan apaapa, tidak dapat menghasilkan sesuatu. Hal ini berkaitan dengan bagaimana anak dapat mengembangkan rasa percaya dirinya untuk memotivasi diri, bersemangat dan bekerja keras untuk keberhasilannya dalam belajar matematika.

Berdasarkan permasalahan yang ada, maka penelitian ini dibatasi pada pengkajian pengaruh kecerdasan emosional terhadap prestasi belajar matematika pada siswa kelas VIII SMP Negeri 1 Kapontori. Prestasi belajar yang dimaksud adalah hasil yang dicapai oleh siswa dari kegiatan pembelajaran matematika di sekolah berupa nilai tes atau nilai angka.

Rumusan masalah dalam penelitian adalah apakah ada pengaruh kecerdasan emosional terhadap prestasi belajar matematika pada siswa kelas VIII SMP Negeri 1 Kapontori?. Berdasarkan rumusan masalah diatas, maka tujuan penelitian ini adalah untuk mengetahui pengaruh kecerdasan terhadap prestasi belajar matematika siswa pada kelas VIII SMP Negeri 1 Kapontori.

Aktifitas-aktifitas siswa SMP Negeri 1 Kapontori dikelas VIII dibimbing dan diarahkan guru matematika untuk menuntunnya dalam belajar matematika melalui keterampilan proses. 
Siswa diajak untuk melibatkan mental, fisik, dan emosinya dalam memperoleh ilmu matematika. Siswa diajak untuk memperhatikan demonstrasi guru di depan kelas, menganalisa dan menyelesaikan permasalahan matematika. Dalam melakukan aktifitas tersebut, siswa dapat merasakan berbagai emosi seperti bersemangat, gembira, atau bosan dan berputus asa. Aktifitas ini melibatkan kecerdasan emosional siswa dalam menanganinya.

Prestasi belajar mengajar matematika tidak hanya bertujuan agar sisi pengetahuan siswa tercapai, tetapi juga agar siswa berpikir secara proses matematika dan untuk menumbuhkan sikap ilmiah. Matematika yang tidak melibatkan keterampilan proses matematika akan menurunkan semangat belajar bagi siswa, menumbuhkan kejenuhan dalam belajar dan putus asa dalam menghadapi kegagalan dalam tes matematika.

Hambatan-hambatan dalam belajar matematika, akan ditemui siswa juga dalam pelajaran lainnya. Siswa dapat mengatasi hambatan-hambatan tersebut akan lebih siap dalam mengikuti proses belajar mengajar di sekolah. Adapun siswa yang mudah merasa kecewa, sedih, frustasi, gelisah dan cemas dalam mengikuti suatu pelajaran, akan kesulitan mengeluarkan kemampuan mental dan intelektual yang dimilikinya dalam belajar.

Siswa yang memiliki kemampuan yang baik akan mengenali emosi diri, memotivasi diri, berempati dan berhubungan dengan orang lain adalah siswa yang memiliki kecerdasan emosional yang baik. Sedangkan siswa yang kesulitan menangani satu atau lebih kemampuan diatas berarti kecerdasan emosionalnya kurang.

Berdasarkan kerangka berpikir diatas, diduga bahwa kecerdasan emosional siswa mempengaruhi prestasi belajar matematika siswa SMP Negeri 1 Kapontori kelas VIII. Siswa yang meiliki kecerdasan emosional stabil diduga akan dapat mengoptimalkan kemampuan dirinya sehingga dapat memiliki prestasi belajar matematika yang tinggi. Adapun siswa yang kecerdasan emosionalnya kurang stabil, dalam belajar matematika diduga akan terlambat intelegensinya akan menjumpai banyak kesulitan dalam belajar matematika sehingga tidak mampu berprestasi dalam pelajaran matematika. Oleh karena itu bisa diduga terdapat pengaruh kecerdasan emosional terhadap prestasi belajar matematika siswa SMP Negeri 1 Kapontori kelas VIII.

Berdasarkan landasan teori dan kerangka pikir yang telah diuraikan, maka hipotesis dalam penelitian ini adalah ada pengaruh kecerdasan emosional terhadap prestasi belajar matematika pada siswa kelas VIII SMP Negeri 1 Kapontori

\section{METODE}

\subsection{Jenis Penelitian}

Jenis penelitian adalah penelitian kuantitatif metode ex-post facto. yaitu untuk menemukan penyebab yang memungkinkan perubahan perilaku, gejala, dan fenomena yang disebabkan oleh suatu peristiwa, perilaku atau hal-hal yang menyebabkan perubahan pada variabel bebas yang secara keseluruhan sudah terjadi dan menjelaskan atau menemukan bagaimana variabel-variabel dalam penelitian saling berhubungan atau berpengaruh. Penelitian ex-post facto ini digunakan karena pada penelitian ini, peneliti tidak memberikan perlakuan terhadap variabel yang diteliti. 


\subsection{Variabel Penelitian}

Pada penelitian ini variabel bebas (independent variabel) dan variabel terikat (dependent variabel) telah dinyatakan secara eksplisit, untuk kemudian dihubungkan sebagai penelitian korelasi atau diprediksikan jika variabel bebas mempunyai pengaruh tertentu dengan variabel terikat, dengan desain seperti pada Gambar 1.

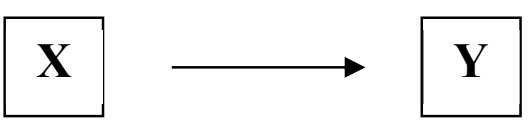

$$
\text { Gambar 1. Desain Penelitian }
$$

Keterangan:

$\mathrm{X}$ : menyatakan nilai variabel hasil analisis kecerdasan emosional (EQ)

Y : menyatakan nilai variabel hasil belajar

\subsection{Waktu dan Tempat Penelitian}

Penelitian ini dilaksanakan di SMP Negeri 1 Kapontori pada semester genap tahun pelajaran 2018/2019 di SMP Negeri 1 Kapontori.

\subsection{Populasi dan Sampel Penelitian}

\section{Populasi Penelitian}

Jenis populasi yang digunakan dalam penelitian ini adalah populasi terhingga, yaitu seluruh siswa kelas VIII SMP Negeri 1 Kapontori yang terdiri dari 3 kelas dengan jumlah 53 orang, dengan distribusi seperti pada Tabel 1.

Tabel 1. Jumlah Peserta Didik Kelas VIII SMP Negeri 1 Kapontori 2018/2019

\begin{tabular}{cccc}
\hline \multirow{2}{*}{ Kelas } & Jumlah & \multicolumn{2}{c}{ Jenis Kelamin } \\
\cline { 3 - 4 } & Siswa & Laki-laki & Perempuan \\
\hline VIII A & 18 & 10 & 8 \\
VIII B & 17 & 8 & 9 \\
VIII C & 18 & 10 & 8 \\
\hline Jumlah & 53 & 28 & 25 \\
\hline
\end{tabular}

\section{Sampel Penelitian}

Dalam pengambilan jumlah sampel, jika subjek kurang dari 100 maka lebih baik diambil semua. Jika subjeknya besar dapat diambil antara 10\%-15\% atau 20\%-25\% atau lebih. Oleh karena populasi kurang dari 100, maka peneliti menjadikan sampel pada penelitiaan ini adalah seluruh populasi yaitu 53 siswa.

\subsection{Instrumen dan Teknik Pengumpulan Data}

\section{Instrumen Penelitian}

\section{Kuesioner}

Kuesioner yang digunakan dalam penelitian ini berdasarkan skala kecerdasan emosional terdiri dari lima aspek, yaitu: 1). Mengenali emosi, 2) Mengelola emosi, 3) Memotivasi diri, 4) Mengenali emosi orang lain, 5) Membina hubungan yang baik dengan orang lain, yang berguna untuk mengukur sejauh mana kecerdasan emosional dipahami peserta didik. Kemudian kelima 
aspek tersebut dijabarkan kedalam 25 item pertanyaan, dengan 14 item bersifat positif, 11 item bersifat negatif.

Skala kecerdasan emosional disusun berdasarkan modifikasi yang berjenjang dari 1 sampai 5. Bila sifat pernyataan favourable (positif) maka responden akan diberi skor 5 jika memilih sangat sesuai (SS), 4 jika memilih sesuai (S), 3 jika memilih ragu-ragu (RR), 2 jika memilih tidak sesuai (TS) dan 1 jika memilih sangat tidak sesuai (STS). Sebaliknya, bila sifat unfavourable (negatif) maka responden akan diberi skor 1 jika memilih sangat sesuai (SS), 2 jika memilih sesuai (S), 3 jika memilih ragu-ragu (ragu-ragu), 4 jika memilih tidak sesuai (TS) dan 5 jika memilih sangat tidak sesuai (STS).

Sebelum kuisioner ini digunakan terlebih dahulu diuji validitasnya. Validitas yang di gunakan adalah validitas isi dan validitas konstruk. Validitas isi adalah derajat dimana sebuah tes evaluasi mengukur cakupan substansi yang ingin diukur. Validitas isi mencakup hal-hal yang berkaitan dengan apakah item-item evaluasi menggambarkan pengukuran dalam cakupan yang ingin diukur. Validitas isi mempunyai pernanan penting dan umumnya ditentukan melalui pertimbangan para ahli. Tidak ada formula matematis untuk menghitung dan tidak ada cara untuk menunjukkan secara pasti. Para ahli menginterprestasi tes atau melakukan perbandingan antara apa yang harus dimasukan dengan apa yang ingin diukur yang telah direfleksikan menjadi tujuan tes (Sukardi, 2009).

Secara teknis peneliti menggunakan program SPSS 22 untuk memvaliditasi instrumen dengan taraf signifikan 5\%. Hasil uji validitas tes dapat dilihat pada Tabel 2.

Tabel 2. Validitas Instrumen Kecerdasan Emosional

\begin{tabular}{llr}
\hline \multicolumn{3}{c}{ KMO and Bartlett's Test } \\
\hline $\begin{array}{l}\text { Kaiser-Meyer-Olkin Measure of Sampling } \\
\text { Adequacy. }\end{array}$ & .468 \\
\hline Bartlett's Test of & Approx. Chi-Square & 995.137 \\
Sphericity & Df & 300 \\
& Sig. & .000 \\
\hline
\end{tabular}

Dari hasil analisis pada Tabel 2 dapat dilihat bahwa nilai Kaiser Meyer Olkin Measure Of Sampling (KMO) sebesar 0,468. Nilai KMO dianggap mencukupi jika lebih dari 0,5. Maka persyaratan KMO belum mencukupi karena $<0.5$. Nilai MSA pada Lampiran 4 ditunjukkan pada baris anti image correlation dengan tanda " $\alpha$ ", ada beberapa item yang bernilai $<0,5$ tetapi pada kasus ini kita mengambil nilai yang paling rendah yaitu pada item 23 yang bernilai $0,239<0,5$ maka item 23 tidak memenuhi syarat MSA. Maka item 23 dikeluarkan dari pengujian, dan kita melakukan analisis faktor seperti langkah sebelumnya. Hasil analisis dapat dilihat pada Tabel 3 .

Tabel 3. Validitas Instrumen Kecerdasan Emosional

\begin{tabular}{llr}
\hline \multicolumn{3}{c}{ KMO and Bartlett's Test } \\
\hline $\begin{array}{l}\text { Kaiser-Meyer-Olkin Measure of Sampling } \\
\text { Adequacy. }\end{array}$ & .507 \\
\hline Bartlett's Test of & Approx. Chi-Square & 910.345 \\
Sphericity & Df & 276 \\
& Sig. & .000 \\
\hline
\end{tabular}


Setelah dianalisis kembali dapat dilihat pada Tabel 3 Nilai KMO sebesar 0,507. Maka persyaratan KMO telah mencukupi karena $>0.05$. Tetapi Pada Tabel anti image ada beberapa item yang berniliai $<0,5$ tetapi pada kasus ini kita mengambil nilai yang paling rendah yaitu pada item 18 yang nilainya $0,267<0,5$ maka item 18 tidak memenuhi syarat MSA. Maka item 18 dikeluarkan dari pengujian. Sehingga kita melakukan analisis faktor seperti langkah sebelumnya. Hasil analisis dapat dilihat pada Tabel 4.

Tabel 4. Validitas Instrumen Kecerdasan Emosional

\begin{tabular}{llr}
\hline \multicolumn{3}{c}{ KMO and Bartlett's Test } \\
\hline $\begin{array}{l}\text { Kaiser-Meyer-Olkin Measure of Sampling } \\
\text { Adequacy. }\end{array}$ & .562 \\
\hline Bartlett's Test of & Approx. Chi-Square & 802.601 \\
Sphericity & Df & 253 \\
& Sig. & .000 \\
\hline
\end{tabular}

Setelah dianalisis kembali dapat dilihat pada Tabel 4 nilai KMO sebesar 0,562. Maka persyaratan KMO sudah mencukupi karena $>0.5$. Pada Tabel anti image ada beberapa item yang berniliai $<0,5$ tetapi pada kasus ini kita mengambil nilai yang paling rendah yaitu pada item 8 yang bernilai $0,285<0,5$ maka item 8 tidak memenuhi syarat MSA. Maka item 8 dikeluarkan dari pengujian. Sehingga kita melakukan analisis faktor seperti langkah sebelumnya sebelumnya. Hasil analisis dapat dilihat pada Tabel 5.

Tabel 5. Validitas Instrumen Kecerdasan Emosional

\begin{tabular}{llr}
\hline \multicolumn{3}{c}{ KMO and Bartlett's Test } \\
\hline $\begin{array}{l}\text { Kaiser-Meyer-Olkin Measure of Sampling } \\
\text { Adequacy. }\end{array}$ & .615 \\
\hline Bartlett's Test of & Approx. Chi-Square & 734.250 \\
Sphericity & Df & 231 \\
& Sig. & .000 \\
\hline
\end{tabular}

Setelah dianalisis kembali dapat dilihat pada Tabel 5 nilai KMO sebesar 0,615. Maka persyaratan KMO sudah mencukupi karena 0,615 $>0.5$. Pada Tabel anti image ada beberapa item yang berniliai $<0,5$ tetapi pada kasus ini kita mengambil nilai yang paling rendah yaitu pada item 13 yang bernilai $0,345<0,5$ maka item 13 tidak memenuhi syarat MSA. Maka item 13 dikeluarkan dari pengujian. Sehingga kita melakukan analisis faktor seperti langkah sebelumnya. Hasil analisis dapat dilihat pada Tabel 6.

Tabel 6. Validitas Instrumen Kecerdasan Emosional

\begin{tabular}{llr}
\hline \multicolumn{3}{c}{ KMO and Bartlett's Test } \\
\hline $\begin{array}{l}\text { Kaiser-Meyer-Olkin Measure of Sampling } \\
\text { Adequacy. }\end{array}$ & .699 \\
\hline Bartlett's Test of & Approx. Chi-Square & 680.928 \\
Sphericity & Df & 210 \\
& Sig. & .000 \\
\hline
\end{tabular}


Setelah dianalisis kembali dapat dilihat pada Tabel 6 nilai KMO sebesar 0,699. Maka persyaratan KMO sudah mencukupi karena 0,699 > 0.5. Pada Tabel anti image ada beberapa item yang berniliai $<0,5$ tetapi pada kasus ini kita mengambil nilai yang paling rendah yaitu pada item 10 yang bernilai $0,485<0,5$ maka item 10 tidak memenuhi syarat MSA. Maka item 10 dikeluarkan dari pengujian. Sehingga kita melakukan analisis faktor seperti langkah sebelumnya. Hasil analisis dapat dilihat pada tabel 7.

Tabel 7. Validitas Instrumen Kecerdasan Emosional

\begin{tabular}{llr}
\hline \multicolumn{3}{c}{ KMO and Bartlett's Test } \\
\hline $\begin{array}{l}\text { Kaiser-Meyer-Olkin Measure of Sampling } \\
\text { Adequacy. }\end{array}$ & .720 \\
\hline Bartlett's Test of & Approx. Chi-Square & 622.887 \\
Sphericity & Df & 190 \\
& Sig. & .000 \\
\hline
\end{tabular}

Setelah dianalisis kembali dapat dilihat pada Tabel 7 nilai KMO sebesar 0,699. Maka persyaratan KMO sudah mencukupi karena 0,699 > 0.5. Pada tabel anti image dapat dilihat bahwa nilai semua itembernilai $>0,5$ maka semua item telah memenuhi syarat MSA.

Dalam melakukan uji validitas, data hasil uji coba instrument kecerdasan emosional diolah menggunakan bantuan software statistik SPSS versi 22.0. Dari Tabel 7 diketahui nilai KMO MSA ( Kaiser-meyer-Olkin Measure of Sampling Adequacy) adalah 0,704 > 0,50 dan nilai Bartlett's Test Of Sphericity (sig.) 0,000<0,05, maka analisis faktor dalam penelitian ini dapat dilanjutkan karena sudah memenuhi persyaratan pertama.

Adapun kriteria pengambilan keputusan untuk menentukan valid atau tidaknya instrumen penelitian, adalah jika $r$ hitung sama dengan atau lebih besar dari harga $r$ tabel pada taraf signifikan 5\%. Jika $r$ hitung diperoleh lebih kecil dari harga $r$ pada tabel taraf signifikan 5\%, maka butir instrumen yang dimaksud dikatakan tidak valid. Butir instrument yang tidak valid tidak digunakan dalam penelitian selanjutnya atau dianggap gugur.

Hasil analisis butir instrumen menunjukkan bahwa dari 25 item terdapat 5 item yang tidak valid atau gugur yaitu item $23,18,8,13$, dan 10. Serta terdapat 20 item yang valid. 20 item tersebut dapat digunakan untuk penelitian.

Berdasarkan Tabel 8, pada kolom komponen yang menunjukkan bahwa ada 20 komponen yang dapat mewakili variabel Pada kolom initial eigenvalues yang dengan SPSS kita tentukan nilainya 1 (satu) varians yang telah diterangkan oleh komponen 1 adalah $6,860 / 20 \times 100 \%=34,301$. Komponen 2 adalah $2,777 / 20 \times 100 \%=13,884$ komponen 3 adalah $1,892 / 20 \times 100 \%=9,460$. Komponen 4 adalah $1,473 / 20 \times 100 \%=7,367$. Komponen 5 adalah $1,372 / 20 \times 100 \%=6,859$. Sehingga total keenam komponen akan mampu menjelaskan variabel sebesar $34.301+13,884+9,460+7,367+6,859=71,871 \%$. Dengan demikian, karena nilai eigenvalues yang ditetapkan 1 , maka nilai total yang akan diambil adalah yang $>1$ yaitu komponen 1, 2, 3, 4, dan 5. 
Tabel 8. Total Variance Explained

\begin{tabular}{lrrrrrr}
\hline \multirow{2}{*}{ Component } & \multicolumn{5}{c}{ Enitial Eigenvalues } & \multicolumn{2}{c}{ Extraction Sums of Squared Loadings } \\
\cline { 2 - 7 } & Total & \% of Variance & Cumulative \% & Total & \% of Variance & Cumulative \% \\
\hline 1 & 6.860 & 34.301 & 34.301 & 6.860 & 34.301 & 34.301 \\
2 & 2.777 & 13.884 & 48.185 & 2.777 & 13.884 & 48.185 \\
3 & 1.892 & 9.460 & 57.645 & 1.892 & 9.460 & 57.645 \\
4 & 1.473 & 7.367 & 65.012 & 1.473 & 7.367 & 65.012 \\
5 & 1.372 & 6.859 & 71.871 & 1.372 & 6.859 & 71.871 \\
6 & .942 & 4.709 & 76.580 & & \\
7 & .897 & 4.486 & 81.066 & & \\
8 & .738 & 3.692 & 84.758 & & \\
9 & .531 & 2.655 & 87.413 & & \\
10 & .501 & 2.505 & 89.918 & & \\
11 & .412 & 2.062 & 91.980 & & \\
12 & .310 & 1.549 & 93.528 & & \\
13 & .287 & 1.433 & 94.961 & & \\
14 & .241 & 1.206 & 96.168 & & \\
15 & .202 & 1.009 & 97.177 & & \\
16 & .160 & .802 & 97.979 & & \\
17 & .145 & .723 & 98.701 & & \\
18 & .107 & .536 & 99.238 & & \\
19 & .089 & .443 & 99.681 & & \\
20 & .064 & .319 & 100.000 & & \\
\hline Exyyyyyy & & & & \\
\end{tabular}

Extraction Method: Principal Component Analysis.

Reliabilitas dinyatakan dengan koefisien reliabilitas yang berada dalam rentang 0,00 hingga 1,00. Semakin tinggi koefisien reliabilitas mendekati angka 1,00 berarti semakin tinggi reliabilitas. Sebaliknya koefisien yang semakin rendah mendekati 0 berarti semakin rendah reliabilitas (Azwar, 2012). Koefisien Alpha Cronbach yang diharapkan dalam sebuah alat ukur minimal adalah $0,6-0,8$.

Teknik yang digunakan untuk menentukan reliabilitas skala dalam penelitian ini adalah teknik analisis varians dari Alpha Cronbach, dengan menggunakan rumus yaitu :

$$
r_{11}=\frac{k}{k-1}\left(1-\frac{\sum \sigma i 2}{\sigma t 2}\right)
$$

dengan:

$r_{11}=$ koefisien reliabilitas angket

$\mathrm{k} \quad=$ banyaknya butir item yang dikeluarkan dalam angket

$1=$ bilangan konstan

$\sum \boldsymbol{\sigma}^{2}=$ jumlah varian skor dari tiap-tiap butir item

$\sigma_{t}^{2}=$ varian total

Untuk memudahkan dalam analisis reliabilitas, dilakukan bantuan SPSS 22. Hasil analisis reliabilitas instrumen dapat dilihat pada Tabel 9.

Tabel 9. Hasil Uji Reliabilitas

\begin{tabular}{rr}
\hline Cronbach's Alpha & Nof Items \\
\hline .880 & 25 \\
\hline
\end{tabular}


Dari Tabel 9 diketahui nilai $N$ of items ada 25 item dengan nilai Cronbach's alpha sebesar 0,880. Karena nilai cronbach's alpha 0,880>0,60 maka kuisioner tersebut dapat dikatakan reliabel atau andal untuk dijadikan instrumen penelitian (Trihendradi, 2012).

Tes yang merupakan instrument dalam penelitian ini adalah tes tertulis berbentuk uraian (essay) sebanyak 5 butir soal, yang disusun oleh peneliti berdasarkan indikator yang ingin dicapai dengan tujuan untuk melihat tingkat pemahaman siswa dalam mempelajari materi yang disampaikan.

\section{Teknik Pengumpulan Data}

Kuesioner merupakan teknik pengumpulan data yang dilakukan dengan cara memberi seperangkat pertanyaan atau pernyataan tertulis kepada responden untuk dijawabnya (Sugiyono, 2011). Jenis kuesioner penelitian ini menggunakan metode skala likert, yaitu skala yg digunakan untuk mengukur sikap, pendapat, dan persepsi seseorang atau kelompok tentang fenomena sosial (variabel penelitian). Pernyataan sikap terdiri atas dua macam yaitu pernyataanfavourable (positif), dan unfavourable (negatif). Skala disajikan dalam bentuk tertutup dengan dimana responden sudah disediakan pilihan jawaban alternatif dan tinggal memilih jawaban yang benar. Kuesioner diberikan 1 hari setelah pemberian tes prestasi belajar. Bentuk tes yang digunakan adalah tes tertulis yang merupakan hasil belajar siswa berbentuk uraian (essay). Tes digunakan ketika semua materi telah diajarkan.

\subsection{Teknik Analisis Data}

Data yang sudah dikumpulkan oleh peneliti kemudian dianalisis sesuai dengan ketentuan dan keinginan penelitian ini sehingga dapat dibaca dan dapat ditafsirkan sebagai hasil peneliti. Hal ini sejalan dengan menurut (Azwar, 2012), Pengolahan data penelitian yang sudah diperoleh dimaksudkan sebagai suatu cara mengorganisasikan data sedemikian rupa sehingga dapat dibaca dan dapat ditafsirkan.

Sebagai syarat penggunaan statistik parametrik, maka sebelum dianalisis terlebih dahulu dilakukan uji asumsi terhadap data yang diperoleh dengan menggunakan uji normalitas, dimana nilai Y (variabel terikat) didistribusikan secara normal terhadap nilai X (variabel bebas). Upaya ini dilakukan untuk menguji apakah dalam sebuah model regresi, variabel dependen dan variabel independen atau keduanya mempunyai distribusi normal atau tidak. Model regresi yang baik adalah distribusi data normal atau mendekati normal. Pedoman yang digunakan untuk normal tidaknya sebaran adalah jika $\mathrm{p}>0,05$ maka data dikatakan normal, sedangkan apabila $\mathrm{p}<0,05$ maka data dikatakan tidak normal. Uji asumsi terdiri dari Uji Normalitas, Uji Heteroskedaksitas, Uji Autokorelasi, dan Uji Linearitas.

Uji normalitas adalah untuk melihat apakah nilai residual terdistribusi normal atau tidak. Model regresi yang baik adalah memiliki nilai residual yang terdistribusi normal. Jadi uji normalitas bukan dilakukan pada masing-masing variabel tetapi pada nilai residualnya. Sering terjadi kesalahan yang jamak yaitu bahwa uji normalitas dilakukan pada masing-masing variabel. Hal ini tidak dilarang tetapi model regresi memerlukan normalitas pada nilai residualnya bukan pada masing-masing variabel penelitian.

Uji heteroskedastisitas adalah untuk melihat apakah terdapat ketidaksamaan varians dari residual satu pengamatan ke pengamatan yang lain. Model regresi yang memenuhi persyaratan 
adalah di mana terdapat kesamaan varians dari residual satu pengamatan ke pengamatan yang lain tetap atau disebut homoskedastisitas.

Deteksi heteroskedastisitas dapat dilakukan dengan metode scatter plot dengan memplotkan nilai ZPRED (nilai prediksi) dengan SRESID (nilai residualnya). Model yang baik didapatkan jika tidak terdapat pola tertentu pada grafik, seperti mengumpul di tengah, menyempit kemudian melebar atau sebaliknya melebar kemudian menyempit. Uji statistik yang dapat digunakan adalah uji Glejser.

Beberapa alternatif solusi jika model menyalahi asumsi heteroskedastisitas adalah dengan mentransformasikan ke dalam bentuk logaritma, yang hanya dapat dilakukan jika semua data bernilai positif. Atau dapat juga dilakukan dengan membagi semua variabel dengan variabel yang mengalami gangguan heteroskedastisitas.

Uji autokorelasi adalah untuk melihat apakah terjadi korelasi antara suatu periode $\mathrm{t}$ dengan periode sebelumnya (t-1). Secara sederhana adalah bahwa analisis regresi adalah untuk melihat pengaruh antara variabel bebas terhadap variabel terikat, jadi tidak boleh ada korelasi antara observasi dengan data observasi sebelumnya.

Uji autokorelasi hanya dilakukan pada data time series (runtut waktu) dan tidak perlu dilakukan pada data cross section seperti pada kuesioner di mana pengukuran semua variabel dilakukan secara serempak pada saat yang bersamaan. Model regresi pada penelitian di Bursa Efek Indonesia di mana periodenya lebih dari satu tahun biasanya memerlukan uji autokorelasi.

Uji linearitas dipergunakan untuk melihat apakah model yang dibangun mempunyai hubungan linear atau tidak. Uji ini jarang digunakan pada berbagai penelitian, karena biasanya model dibentuk berdasarkan telaah teoretis bahwa hubungan antara variabel bebas dengan variabel terikatnya adalah linear. Hubungan antar variabel yang secara teori bukan merupakan hubungan linear sebenarnya sudah tidak dapat dianalisis dengan regresi linear, misalnya masalah elastisitas.

Jika ada hubungan antara dua variabel yang belum diketahui apakah linear atau tidak, uji linearitas tidak dapat digunakan untuk memberikan adjustment bahwa hubungan tersebut bersifat linear atau tidak. Uji linearitas digunakan untuk mengkonfirmasikan apakah sifat linear antara dua variabel yang diidentifikasikan secara teori sesuai atau tidak dengan hasil observasi yang ada. Uji linearitas dapat menggunakan uji Durbin-Watson.

Analisis deskriptif bertujuan untuk memberikan deskripsi mengenai subjek penelitian berdasarkan data variable yang diperoleh dari kelompok subyek yang diteliti dan tidak dimaksudkan untuk pengujian hipotesis (Azwar, 2012). Analisis deskriptif digunakan untuk mendeskripsikan secara umum hasil penelitian yang dilakukan untuk mengetahui kategorisasi tingkatan pada variable $\mathrm{X}$ dan $\mathrm{Y}$. pendeskripsian ini dilakukan pengklasifikasikan skor subjek berdasarkan norma yang ditentukan.

Perhitungan norma dilakukan untuk melihat tingkat kecerdasan emosional dan prestasi belajar, sehingga dapat diketahui tingkatnya apakah tinggi, sedang, atau rendah. Dalam melakukan pengkategorian ini, peneliti menggunakan skor empiris, dengan langkah-langkah sebagai berikut: Menghitung Mean empiris (M); Menghitung Standar Deviasi (SD); dan Kategorisasi.

Rendah : $X<M-I S D$

Sedang : $M-I S D<X \leq M+I S D$

Tinggi $: X>M+$ ISD 
Analisis inferensial dimaksudkan untuk mengambilini dimaksudkan untuk mengambil kesimpulan dengan pengujian hipotesis untuk keputusan dengan menguji hipotesis (Azwar, 2012). Analisis inferensial digunakan untuk mengetahui hubungann atau pengaruh antara variabel bebas terhadap variabel terikat. Rancangan statistik yang digunakan untuk menganalisis data pengaruh kecerdasan emosional terhadap prestasi belajar adalah: Teknik analisis regresi linear sederhana; menguji keberartian Regresi dengan kaidah pengujian dengan $\alpha=0,05$ dan derajat kebebasan $(\mathrm{dk}=\mathrm{n}-2)$ yaitu jika $\mathrm{t}_{\mathrm{hitung}}>\mathrm{t}_{\text {tabel }}$ maka Ha diterima dan $\mathrm{H} 0$ ditolak, jika $t_{\text {hitung }}<\mathrm{t}_{\text {tabel }}$ maka $\mathrm{H}_{0}$ diterima dan $\mathrm{H}_{1}$ ditolak; dan Menghitung nilai Determinasi, untuk mengetahui pengaruh kecerdasan emosional siswa $(\mathrm{X})$ terhadap prestasi belajar siswa (Y) digunakan perhitungan koefisien determinasi $\left(\mathrm{r}^{2}\right)$ dengan menggunakan rumus

$$
\mathrm{KD}=\mathrm{r}^{2} \times 100 \%
$$

Keterangan:

KD : koefisien determinasi

r $\quad$ : nilai koefisien korelasi

\section{HASIL DAN PEMBAHASAN}

\subsection{Hasil Penelitian}

\section{Analisis Uji Deskriptif}

Perhitungan analisis deskriptif kecerdasan emosional dan prestasi belajar dapat dilihat pada hasil analisis dengan menggunakan program SPSS pada Tabel 10.

Tabel 10. Deskriptif Kecerdasan Emosional dan Prestasi Belajar

\begin{tabular}{|c|c|c|c|}
\hline \multicolumn{4}{|c|}{ Statistics } \\
\hline & & $\begin{array}{c}\text { Kecerdasan } \\
\text { Emosional }\end{array}$ & Prestasi Belajar \\
\hline \multirow[t]{2}{*}{$\mathrm{N}$} & Valid & 53 & 53 \\
\hline & Missing & 0 & 0 \\
\hline \multicolumn{2}{|c|}{ Mean } & 77.91 & 68.87 \\
\hline \multicolumn{2}{|c|}{ Std. Error of Mean } & 1.285 & 1.031 \\
\hline \multicolumn{2}{|c|}{ Median } & 77.00 & 70.00 \\
\hline \multicolumn{2}{|c|}{ Mode } & 87 & $65^{\mathrm{a}}$ \\
\hline \multicolumn{2}{|c|}{ Std. Deviation } & 9.357 & 7.509 \\
\hline \multicolumn{2}{|c|}{ Variance } & 87.549 & 56.386 \\
\hline \multicolumn{2}{|c|}{ Skewness } & -1.054 & .013 \\
\hline \multicolumn{2}{|c|}{ Std. Error of Skewness } & .327 & .327 \\
\hline \multicolumn{2}{|c|}{ Kurtosis } & 2.144 & -.831 \\
\hline \multicolumn{2}{|c|}{ Std. Error of Kurtosis } & .644 & .644 \\
\hline \multicolumn{2}{|c|}{ Range } & 46 & 30 \\
\hline \multicolumn{2}{|c|}{ Minimum } & 48 & 55 \\
\hline \multicolumn{2}{|c|}{ Maximum } & 94 & 85 \\
\hline \multicolumn{2}{|c|}{ Sum } & 4129 & 3650 \\
\hline & 25 & 73.00 & 65.00 \\
\hline & 50 & 77.00 & 70.00 \\
\hline & 75 & 86.50 & 75.00 \\
\hline
\end{tabular}

a. Multiple modes exist. The smallest value is shown 
Tampak pada Tabel 10 bahwa: 1) rata-rata data kecerdasan emosional sebesar 77.91 dengan simpangan baku sebesar 9.375, median sebesar 77.00 dan modus sebesar 87, dan 2) rata-rata data tes prestasi belajar matematika sebesar 68.87 dengan simpangan baku sebesar 7.509, median sebesar 70.00, dan modus sebesar 65 .

\section{Analisis Uji Asumsi}

Uji normalitas adalah untuk melihat apakah nilai residual terdistribusi normal atau tidak. Model regresi yang baik adalah memiliki nilai residual yang terdistribusi normal. Jadi uji normalitas bukan dilakukan pada masing-masing variabel tetapi pada nilai residualnya. Untuk menguji normalitas data peneliti menggunakan uji Kolmogorov-Sminorv Test dengan taraf signifikan $(\alpha)=5 \%$. Uji ini dilakukan dengan bantuan SPSS 22. Data berdistribusi normal jika nilai signifikan $>(\alpha)$. Berdasarkan perhitungan dengan uji Kolmogorov-Sminorv Test tampak pada Tabel 11. Berdasarkan Tabel 11 diperoleh nilai signifikan asyimp.sig (2-tailed) sebesar 0,200 lebih besar dari 0,05. Maka dapat disimpulkan bahwa data berdistribusi normal.

Tabel 11. Uji Normalitas Angket dan Tes

\begin{tabular}{lrr}
\hline \multicolumn{3}{c}{ One-Sample Kolmogorov-Smirnov Test } \\
\hline \multicolumn{3}{c}{$\begin{array}{c}\text { Unstandardized } \\
\text { Residual }\end{array}$} \\
\hline $\mathrm{N}$ & 53 \\
Normal & Mean & .0000000 \\
Parameters ${ }^{\mathrm{a}, \mathrm{b}}$ & Std. Deviation & 5.26641270 \\
Most Extreme & Absolute & .097 \\
Differences & Positive & .097 \\
& Negative & -.065 \\
Test Statistic & & .097 \\
Asymp. Sig. (2-tailed) & $.200^{\mathrm{c}, \mathrm{d}}$ \\
\hline a. Test distribution is Normal. \\
b. Calculated from data. \\
c. Lilliefors Significance Correction. \\
d. This is a lower bound of the true significance.
\end{tabular}

Uji heteroskedastisitas adalah untuk melihat apakah terdapat ketidaksamaan varians dari residual satu kepengamatan yang lain. Untuk menguji heteroskedastisitas data peneliti menggunakan uji Glejser dengan taraf signifikan $(\alpha)>0,05$ tidak terjadi heteroskedastisitas dan taraf signifikan $(\alpha)<0,05$ terjadi heteroskedastisitas. Uji ini dilakukan dengan bantuan SPSS 22. Berdasarkan perhitungan dengan uji Glejser tampak pada Tabel 12. Berdasarkan Tabel 12 diperoleh nilai sig. 0,469 $>0.05$ sehingga dapat disimpulkan bahwa data tidak terjadi heteroskedastisitas.

Tabel 12. Uji Glejser Instrumen

\begin{tabular}{|c|c|c|c|c|c|}
\hline \multicolumn{6}{|c|}{ Coefficients $^{a}$} \\
\hline \multirow[b]{2}{*}{ Model } & \multicolumn{2}{|c|}{$\begin{array}{l}\text { Unstandardized } \\
\text { Coefficients }\end{array}$} & \multirow{2}{*}{$\begin{array}{c}\begin{array}{c}\text { Standardized } \\
\text { Coefficients }\end{array} \\
\text { Beta }\end{array}$} & \multirow[b]{2}{*}{$\mathrm{t}$} & \multirow[b]{2}{*}{ Sig. } \\
\hline & $\mathrm{B}$ & Std. Error & & & \\
\hline $\begin{array}{ll}1 & \text { (Constant) }\end{array}$ & 6.825 & 3.505 & & 1.947 & .057 \\
\hline $\begin{array}{l}\text { Kecerdasan } \\
\text { Emosional }\end{array}$ & -.033 & .045 & -.102 & -.729 & .469 \\
\hline
\end{tabular}

a. Dependent Variable: abs_res 
Tabel 13. Uji Autokorelasi

\begin{tabular}{lccccc}
\hline \multicolumn{5}{c}{ Model Summary $^{\mathbf{b}}$} \\
\hline Model & $R$ & $R$ Square & $\begin{array}{c}\text { Adjusted } R \\
\text { Square }\end{array}$ & $\begin{array}{c}\text { Std. Error of the } \\
\text { Estimate }\end{array}$ & Durbin-Watson \\
\hline 1 & $.713^{\mathrm{a}}$ & .508 & .498 & 5.318 & 1.515 \\
\hline $\begin{array}{l}\text { a. Predictors: (Constant), Kecerdasan Emosional } \\
\text { b. Dependent Variable: Prestasi Belajar }\end{array}$
\end{tabular}

Untuk menguji autokorelasi peneliti menggunakan uji Durbin-Watson dengan taraf signifikan $(\alpha)=5 \%$. Uji ini dilakukan dengan bantuan SPSS 22 seperti pada Tabel 13 . Berdasarkan Tabel 13 tersebut terlihat bahwa nilai Durbin-Watson 1.515. Nilai ini dibandingkan dengan nilai tabel signifikan 5\%. Jumlah sampel 53(n) dan jumlah variable independen $1(\mathrm{k}=1)=1.53$. Nilai 1.53 dapat dilihat pada tabel Durbin Watson. Maka diperoleh nilai dU 1.5951. Nilai DW 1.515 lebih besar dari batasan atas (dU) yakni 1.5951 dan kurang dari (4-du) $4-1.5951=2.4049$. Dapat disimpulkan bahwa tidak terdapat autokorelasi dan hipotesis diterima.

Untuk menguji linearitas menggunakan bantuan SPSS versi 22. Dengan taraf signifikan $5 \%$. Data memiliki hubungan yang linear secara signifikan antara variabel independen dengan variabel dependen jika nilai signifikan $>(\alpha)$. Berdasarkan perhitungan dengan uji linearitas tampak pada Tabel 14. Berdasarkan Tabel 14 Nilai Signifikan (sig) dari deviation frim linearity adalah 0.058 lebih besar dari 0,05. Maka dapat disimpulkan bahwa ada hubungan linear secara signifikan antara variabel kecerdasan emosional (X) dengan prestasi belajar (Y).

Tabel 14. Uji Linearitas Instrumen

\begin{tabular}{|c|c|c|c|c|c|c|c|}
\hline \multicolumn{8}{|c|}{ ANOVA Table } \\
\hline & & & $\begin{array}{l}\text { Sum of } \\
\text { Squares }\end{array}$ & df & $\begin{array}{l}\text { Mean } \\
\text { Square }\end{array}$ & $\mathrm{F}$ & Sig. \\
\hline Prestasi & Between & (Combined) & 2247.552 & 20 & 112.378 & 5.253 & .000 \\
\hline Belajar * & Groups & Linearity & 1489.850 & 1 & 1489.850 & 69.647 & .000 \\
\hline Kecerdasan & & Deviation & & & & & \\
\hline Emosional & & $\begin{array}{l}\text { from } \\
\text { Linearity }\end{array}$ & 757.702 & 19 & 39.879 & 1.864 & .058 \\
\hline \multicolumn{3}{|c|}{ Within Groups } & 684.524 & 32 & 21.391 & & \\
\hline & \multicolumn{2}{|c|}{ Total } & 2932.075 & 52 & & & \\
\hline
\end{tabular}

Seteleh dilakukan uji prasyarat terhadap kedua sampel tersebut selanjutnya dilakukan uji hipotesis, hipotesis dilakukan untuk mengetahui apakah ada pengaruh kecerdasan emosional terhadap prestasi belajar matematika pada siswa kelas VIII SMP Negeri 1 Kapontori. Secara umum persamaan regresi linear sederhana adalah $Y=a+b X$ sementara untuk mengetahui nilai koefisien regresi tersebut kita dapat berpedoman pada output yang berada pada Tabel 15 .

Tabel 15. Hipotesis Kecerdasan Emosional dan Prestasi Belajar

\begin{tabular}{|c|c|c|c|c|c|c|}
\hline \multicolumn{7}{|c|}{ Coefficients $^{\mathbf{a}}$} \\
\hline & \multirow[t]{2}{*}{ Model } & \multicolumn{2}{|c|}{ Unstandardized Coefficients } & \multirow{2}{*}{$\begin{array}{c}\text { Standardized } \\
\text { Coefficients } \\
\text { Beta }\end{array}$} & \multirow[t]{2}{*}{$\mathrm{t}$} & \multirow[t]{2}{*}{ Sig. } \\
\hline & & B & Std. Error & & & \\
\hline \multirow[t]{2}{*}{1} & (Constant) & 24.301 & 6.183 & & 3.930 & .000 \\
\hline & $\begin{array}{l}\text { Kecerdasan } \\
\text { Emosional }\end{array}$ & .572 & .079 & .713 & 7.258 & .000 \\
\hline
\end{tabular}

a. Dependent Variable: Prestasi Belajar 
Dalam Tabel 15 nilai konstan sebesar 24.301. Angka ini merupakan angka konstan yang mempunyai arti bahwa jika tidak ada kecerdasan emosional $(\mathrm{X})$ maka nilai prestasi belajar (Y) adalah sebesar 24.301. nilai kecerdasan emosional sebesar 0.572. Angka ini mengandung arti bahwa setiap penambahan 1\% tingkat kecerdasan emosional, maka prestasi belajar (Y) akan meningkat sebesar 0.572. Dengan demikian dapat dikatakan bahwa kecerdasan emosional (X) berpengaruh terhadap prestasi belajar $(\mathrm{Y})$. Sehingga persamaan regresinya adalah $Y=24.301+0.572 X$.

Dilihat dari nilai signifikan yaitu $0,000<$ probabilitas yaitu 0,05 sehingga dapat disimpulkan bahwa $\mathrm{H} 0$ ditolak dan $\mathrm{H} 1$ diterima yang berarti bahwa ada pengaruh kecerdasan emosional terhadap prestasi belajar. Untuk mengetahui besarnya pengaruh variabel $\mathrm{X}$ terhadap variabel Y, kita dapat berpedoman pada nilai $R$ Square atau R2 yang terdapat pada Tabel 16.

Tabel 16. Hasil Hipotesis

\begin{tabular}{llrrr}
\hline \multicolumn{5}{c}{ Model Summary } \\
\hline Model & $\mathrm{R}$ & $\mathrm{R}$ Square & Adjusted R Square & Std. Error of the Estimate \\
\hline 1 & $.713^{\mathrm{a}}$ & .508 & .498 & 5.318 \\
\hline
\end{tabular}

Dari Tabel 16 diketahui bahwa nilai R Square sebesar 0.508. Nilai ini mengandung arti bahwa pengaruh kecerdasan emosional $(\mathrm{X})$ terhadap prestasi belajar $(\mathrm{Y})$ dengan total pengaruh sebesar 50.8\% sedangkan $49.2 \%$ prestasi belajar dipengaruhi oleh variabel lain yang tidak diteliti. Maka dapat disimpulkan bahwa kecerdasan emosional berpengaruh terhadap prestasi belajar dengan total pengaruh $50.8 \%$. Pengaruh ini bermakna semakin menurunnya kecerdasan emosional seseorang maka akan berpengaruh terhadap peningkatan prestasi belajar siswa tersebut. Dari hasil analisis uji asumsi bahwa diketahui $\mathrm{H}_{0}$ ditolak, artinya ada pengaruh kecerdasan emosional terhadap prestasi belajar siswa SMP Negeri 1 Kapontori.

\subsection{Pembahasan}

Ada pengaruh kecerdasan emosional terhadap prestasi belajar siswa di SMP Negeri 1 Kapontori dibuktikan dari nilai Sig. sebesar $0.00<0.05$ Dengan demikian, pengujian menunjukkan $\mathrm{H}_{0}$ ditolak $\mathrm{H}_{1}$ diterima. Oleh karena itu dapat disimpulkan dari hasil tersebut yang memperlihatkan bahwa variabel kecerdasan emosional berpengaruh terhadap prestasi belajar siswa.

Hasil penelitian ini sesuai menurut Salovey sebagaimana dikutip oleh Goleman bahwa kecerdasan emosional dibagi kedalam lima wilayah, yaitu: mengenali diri, mengelola emosi diri, memotivasi diri sendiri, mengenali emosi orang lain dan membina hubungan. Kecerdasan emosi sebagai kemampuan untuk memotivasi diri sendiri, dan kemampuan mengelola emosi dengan baik pada diri sendiri dan dalam hubungan dengan orang lain. Kecerdasan emosi sangat penting mengingat didalamnya terdapat sebuah interaksi antara manusia yang memerlukan kemampuan bagaimana seseorang mampu mengelola emosinya ketika bersosialisasi dan komunikasi dengan orang lain.

Dengan adanya kecerdasan emosional seseorang itu mampu memegang kendali emosi dan mampu mengelola perasaannya, maka ia akan jauh dari konflik yang ada dalam pribadinya, pada dasarnya adalah bagaimana seseorang itu mampu mengoptimalkan dalam proses pengendalian emosi yang ada pada dirinya, ia akan lebih mampu mengontrol dalam segala keputusan yang akan ia jalankan, akan lebih berhati-hati dalam setiap pengambilan keputusan 
dan juga menghargai sebuah keputusan yang telah ia buat dan konsekwensinya ia sendiri yang akan menanggung. Demikianlah, kenapa kecerdasan emosional sangat menentukan keberhasilan seseorang dalam hidup, jadi perlu kajian yang lebih dalam menyikapi tentang kecerdasan emosi ini sehingga potensi-potensi sosial akan terwujud ketika kecerdasan emosi ini mampu dijalankan dengan cara seksama dan kontinu untuk pencapaian kehidupan yang lebih baik.

Prestasi belajar adalah hasil pencapaian dari usaha yang dikerjakan baik secara individul atau kelompok. Dengan demikian, kecerdasan emosional dapat mempengaruhi prestasi belajar siswa. Tujuan belajar yang ditekankan oleh taksonomi Bloom ada tiga kawasan, yaitu; 1) domain kognitif, yang terdiri atas 6 (enam) tingkatan, yaitu pengetahuan, pemahaman, aplikasi, analisis, sintesis, dan evaluasi, 2) domain afektif, yang terdiri dari 5 (lima) tingkatan, yaitu penerimaan, tanggapan, penanaman nilai, pengorganisasian nilai, dan karakteristik kehidupan, 3) domain psikomotorik, yang terdiri lima tingkatan, yaitu memperhatikan, peniruan, penggunaan, perangkaian, dan penyesuaian/naturalisasi.

\section{SIMPULAN}

Berdasarkan hasil penelitian dari pembahasan, maka dapat diambil kesimpulan bahwa ada pengaruh kecerdasan emosional terhadap prestasi belajar matematika siswa kelas VIII SMP Negeri 1 Kapontori.

\section{DAFTAR PUSTAKA}

Azwar, S. (2012). Reliabilitas dan Validitas. Pustaka Pelajar.

Firmansyah, I. (2010). Pengaruh Tingkat Kecerdasan Emosional terhadap Prestasi Belajar Siswa SMA Triguna Utama Ciputat [Universitas Islam Negeri Syarif Hidayatullah]. https://www.academia.edu/34297758

Goleman, D. (2015). Emotional Intelligence, Kecerdasan Emosional Mengapa EI Lebih Penting daripada IQ. PT Gramedia Pustaka Utama.

Gottman, J., Declaire, J., \& Goleman, D. (1998). Raising An Emotionally Intelligent Child The Heart of Parenting. In Simon Schuster Paperbacks. Simon \& Schuster.

Gusniwati, M. (2015). Pengaruh Kecerdasan Emosional dan Minat Belajar terhadap Penguasaan Konsep Matematika Siswa SMAN di Kecamatan Kebon Jeruk. Jurnal Formatif: Jurnal Ilmiah Pendidikan MIPA, 5(1), 26-41. https://doi.org/10.30998/formatif.v5i1.165

Rosida, V. (2015). Pengaruh Kecerdasan Emosional Terhadap Hasil Belajar Matematika Siswa Kelas VII2 SMP Negeri 1 Makassar. Jurnal Sainsmat, 4(2), 87-101. https://doi.org/10.35580/sainsmat4218362015

Sugiyono. (2011). Metode Penelitian Kuantitatif, Kualitatif dan R\&D. Alfabeta.

Sukardi. (2009). Metodologi Penelitian Pendidikan(Kompetensi dan Praktiknya). Bumi Aksara.

Trihendradi, C. (2012). Step by Step SPSS 20 : Analisis Data Statistik. Andi. 